\title{
Early detection of Chlamydia trachomatis using fluorescent, DNA binding dyes
}

\author{
S. H. SALARI AND M. E. WARD
}

From the Department of Microbiology, Southampton University Medical School, Southampton General Hospital, Tremona Road, Southampton SO9 $4 X Y$, UK

SUMMARY HeLa 229 cells were infected with genital tract strains of Chlamydia trachomatis. After incubation for varying times the infected cells were fixed and stained with the fluorescent DNA binding dyes Hoechst 33258 or DAPI for comparison with conventional Giemsa stain. Fluorochrome-treated preparations were examined by incident ultraviolet fluorescence microscopy and the Giemsa-stained preparations by dark-ground light microscopy. Chlamydial inclusion bodies could be identified unambiguously as early as 18 hours after infection of HeLa 229 cells using either Hoechst 33258 or DAPI but not until some 48 hours in Giemsa-stained preparations. The DNA rich chlamydial elementary bodies in infected egg yolk suspension were readily detected using Hoechst 33258. The fluorescent dye technique was simpler and more rapid than Giemsa staining. Using Hoechst 33258 it is possible to speed up the identification of chlamydial isolates growing in tissue culture.

Chlamydiae are prokaryotic microorganisms structurally related to bacteria but lacking the energy systems necessary for independent existence. Unlike bacteria they undergo a complex growth cycle initiated by infection of the host cell with DNA rich, $0.3 \mu \mathrm{m}$ diameter, elementary bodies. The elementary bodies enlarge to form the metabolically active, $1 \mu \mathrm{m}$ diameter, RNA rich, reticulate bodies. These reticulate bodies divide and multiply within host cell vacuoles, giving rise to a characteristic inclusion body. Ultimately, elementary bodies differentiate from the reticulate bodies and are released from the cell some 48-72 hours after infection.

Chlamydia trachomatis infections are diagnosed by growth of the agent in specially prepared tissue culture cells for some three days. The culture is then examined for the characteristic, glycogen-containing inclusion bodies using iodine, fluorescent antibody, or Giemsa stain. Giemsa-stained inclusions are more readily visualised using dark-ground microscopy (Darougar et al., 1971). This paper describes a novel method of staining chlamydial inclusions, which permits the unambiguous detection of developing chlamydial reticulate bodies in tissue culture for the common genital tract strains after only 18 hours'

Received for publication 27 April 1979 growth. The method exploits the ability of Hoechst 33258 , a benzimidazole compound, specifically to form a fluorescent complex with DNA but not RNA by selective binding to the adenine-thymine rich regions of double-stranded DNA (Arndt-Jovin and Jovin, 1977).

\section{Methods}

\section{MATERIAL}

C. trachomatis strains UW4/GCX (serotype H), IOL-238/R (serotype G), and LGV.440/LN (serotype $L_{1}$ ) were kindly provided by $\mathrm{Dr} S$. Darougar, Institute of Ophthalmology, London. The strains were passaged once through the yolk sac of embryonated hens' eggs and then frozen at $-70^{\circ} \mathrm{C}$.

Hoechst $33258^{1}$ was obtained through the kind auspices of Mr J. W. Neaves, Hoechst UK Limited, Salisbury Road, Hounslow, Middx, UK. DAPI (4'-6-diamidino-2-phenylindole hydrochloride) was originally obtained from Professor $\mathbf{O}$. Dann, Institut für angewandte Chemie, 852 Erlangen, West Germany and is now available commercially from Serva Feinbiochemica, PO Box 1052 60, Heidelberg D-69, West Germany. Diethylamino ethyl dextran

${ }^{1}$ Bisbenzimide trihydrochloride. Now available from Aldrich Chemical Co Ltd, Gillingham, Dorset, UK 
(DEAE dextran) of molecular weight 500000 was obtained from Sigma Chemicals, Poole, Dorset, UK.

\section{TISSUE CULTURE}

HeLa 229 cells (Flow Labs, Irvine, Scotland) were grown to confluent monolayers on $13 \mathrm{~mm}$ diameter coverslips in disposable bijoux. Each bijou contained $1 \mathrm{ml}$ of Eagle's Minimal Essential Medium, $10 \% \mathrm{v} / \mathrm{v}$ Foetal Calf Serum, $1 \% \mathrm{v} / \mathrm{v}$ non-essential amino acids, L-glutamine and sodium bicarbonate (Flow Labs) without antibiotics. The bijoux were inoculated with $100 \mu$ l volumes of a 1 in 100 dilution of $50 \%$ egg lethal dose chlamydiae and incubated for 3 hours at $35^{\circ} \mathrm{C}$ for UW4 and IOL 238 or $37^{\circ} \mathrm{C}$ for LGV to permit chlamydial adsorption. Before adsorption the infectivity of strains UW4 and IOL 238 was potentiated by washing the cells twice with $45 \mu \mathrm{g} / \mathrm{ml}$ of DEAE-dextran in Hanks salts followed by centrifugation of the chlamydiae on to the cells at $900 \mathrm{~g}$ for 1 hour (Kuo et al., 1971; 1972).

\section{STAINING}

Chlamydial infected monolayers on $13 \mathrm{~mm}$ diameter No. 1 coverslips were washed twice with complete Dulbecco's phosphate buffered saline (PBS, Oxoid Limited) and fixed for 10 minutes with absolute methanol. The fixed cells were washed twice with PBS and then incubated for 10 minutes at $37^{\circ} \mathrm{C}$ with a freshly prepared solution of $10 \mu \mathrm{g} / \mathrm{ml}$ of Hoechst 33258 or DAPI in PBS. Stained cells were washed twice with PBS, dried, and mounted in
$50 \% \mathrm{v} / \mathrm{v}$ glycerol in PBS cell surface down on a microscope slide for fluorescence microscopy. For comparative purposes chlamydial infected cells were stained in parallel with Giemsa stain (Johnson, 1975). As both Hoechst 33258 and DAPI bind to DNA they are possible carcinogens and should be handled accordingly.

\section{MICROSCOPY}

Hoechst 33258 or DAPI stained material was examined with an Ortholux II microscope (E. Leitz, Wetzlar, West Germany) fitted with an HBO 200 ultraviolet source and Ploem 1 incident light illumination. The filters used were: a $4 \mathrm{~mm}$ BG38 in the lamphouse, $2 \times 2 \mathrm{~mm}$ UG 1 filters for narrow band excitation at $365 \mathrm{~nm}$, a TK 400/K400 dichroic mirror and suppression filter, and a K460 (460 nm) barrier filter.

Giemsa-stained material was examined using an Ortholux II microscope equipped with an oil immersion NA 1.2 dark-ground condenser.

\section{Results}

Figure 1 is a fluorescence micrograph showing the result of staining uninfected HeLa 229 cells with Hoechst 33258. Figure 2 shows the results of a parallel experiment, in which the cells were infected with LGV $\mathbf{4 4 0}$ for 48 hours. Chlamydial inclusions can readily be detected between the brightly fluorescent host cell nuclei. Lymphogranuloma venereum (LGV)

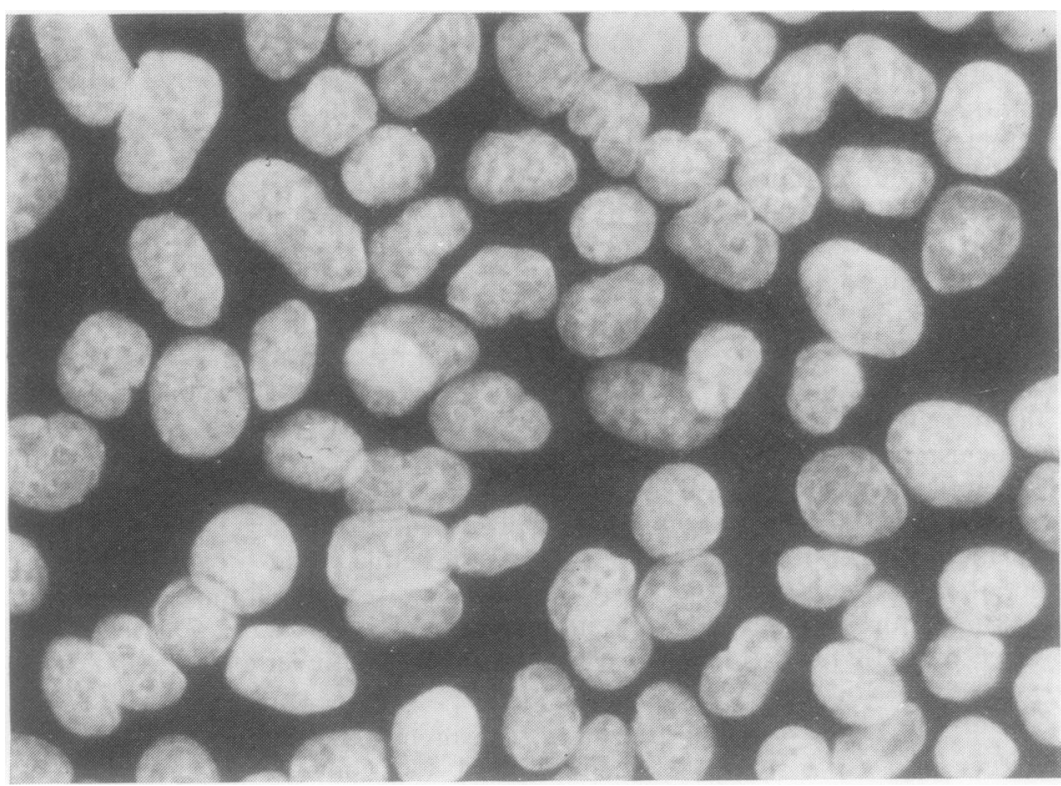

Fig. 1 Uninfected HeLa 229 cells monolayer stained with Hoechst 33258 for 10 minutes and examined by incident ultraviolet fluorescence microscopy. Only the host cell nuclei are stained. $\times 400$. 


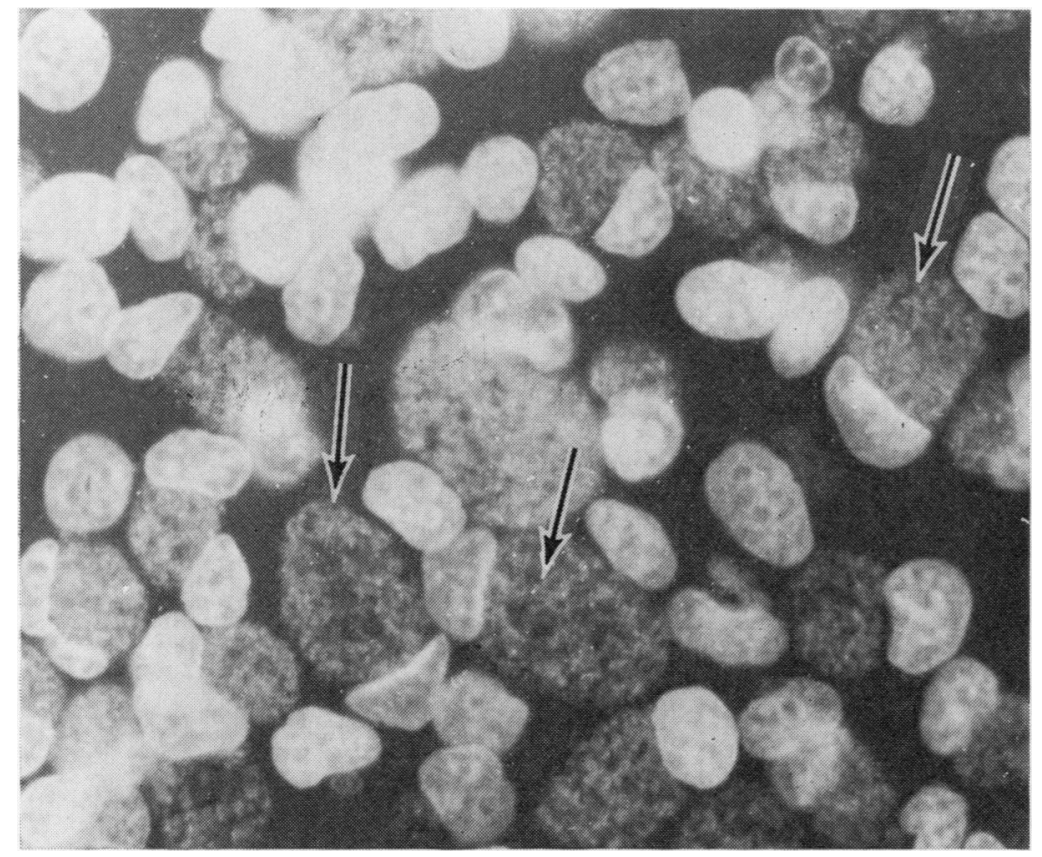

Fig. 2 Fluorescence photomicrograph of Hoechst 33258 stained HeLa 229 cells infected for 48 hours with C. trachomatis LGV 440. Chlamydial inclusions (arrows) can readily be seen between the brightly fluorescent nuclei. $\times 350$.

chlamydiae differ from United Kingdom isolates of $C$. trachomatis in that they have a shorter growth cycle, do not require centrifugation to establish in vitro infection, and form larger inclusions. The experiment was repeated using two typical genital tract $C$. trachomatis strains, UW4 and IOL 238, taking samples after $1,12,18,24,36,42,48,60$, and 72 hours' incubation and comparing in parallel Hoechst 33258 and Giemsa-stained material.

In the Hoechst 33258 stained preparations, no significant differences could be seen between uninfected and chlamydial infected cells after 12 hours' incubation. However, after 18 hours' incubation definite chlamydial inclusions could be seen in the infected cells (Fig. 3). These inclusions were characteristically granular, consisting of approximately $1 \mu \mathrm{m}$ reticulate bodies, and, being less rich in DNA, they were less fluorescent than the host cell nucleus. By 24 hours the inclusions were noticeably enlarged and at 36 hours were much more brightly fluorescent due to the development of DNA rich elementary bodies. The inclusions continued to enlarge up to 60 hours' incubation (Fig. 4), and by 72 hours large numbers of chlamydiae had been released from the cells. After 72 hours' incubation brightly fluorescent (DNA rich) particles of a similar size to chlamydial elementary bodies could be seen attached to the surface of the tissue culture cells (Fig. 5). Small, immature inclusions were also noted in 72-hour preparations as well as the large primary inclusions (Fig. 5). In view of the experimental conditions used, in which the concentration and molecular weight of DEAE-dextran was optimally titrated for the chlamydial strain so as to achieve a high rate of infectivity, it is believed that these small inclusions represent a limited cycle of reinfection occurring in the absence of further centrifugation. Mature chlamydial inclusions of strains UW4 or IOL 238 developing after 60 or 72 hours' incubation were readily detected by dark-ground microscopy in Giemsa-stained preparations (Fig. 6). However, in our culture system immature chlamydial inclusions in HeLa 229 cells infected for less than 48 hours could not be unambiguously detected by the dark-ground Giemsa stain technique. Chlamydial elementary bodies with their high ratio of DNA: RNA were readily identified as small, brightly fluorescent particles against an unstained background in Hoechst 33258 stained smears of chlamydial infected egg yolk sac (Fig. 7).

\section{Discussion}

Non-gonococcal urethritis (NGU) is now more common than gonorrhoea and $C$. trachomatis can be isolated from approximately half these patients. Such infections cannot be regarded as trivial as C. trachomatis has been isolated direct from the 


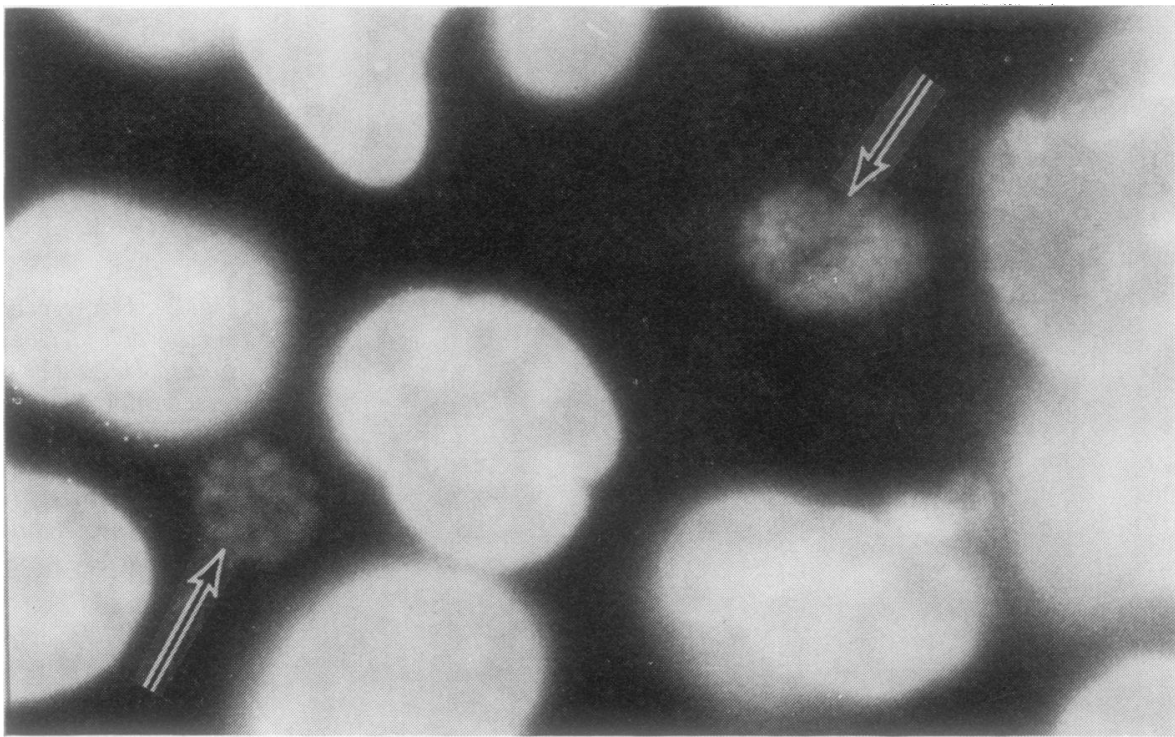

Fig. 3 18-hour inclusions (arrowed) of C. trachomatis UW4 in HeLa 229 cells after staining with Hoechst 33258. The characteristically granular nature of the inclusions can be seen. $\times 1000$.

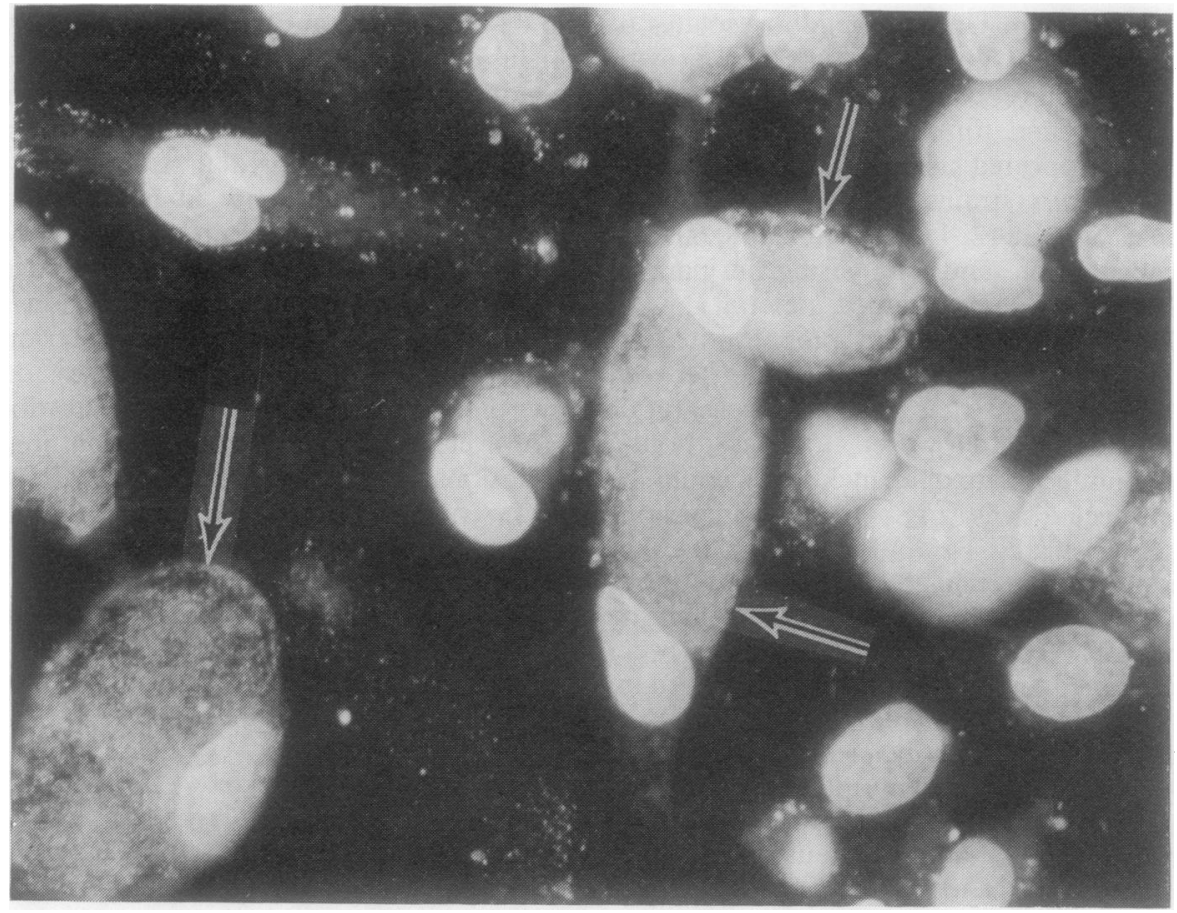

Fig. 4 DAPI stained HeLa 229 cells after infection with C. trachomatis IOL 238 for 60 hours. The chlamydial inclusions are now larger and more brightly fluorescent due to the presence of large numbers of the DNA rich elementary bodies. $\times 400$. 


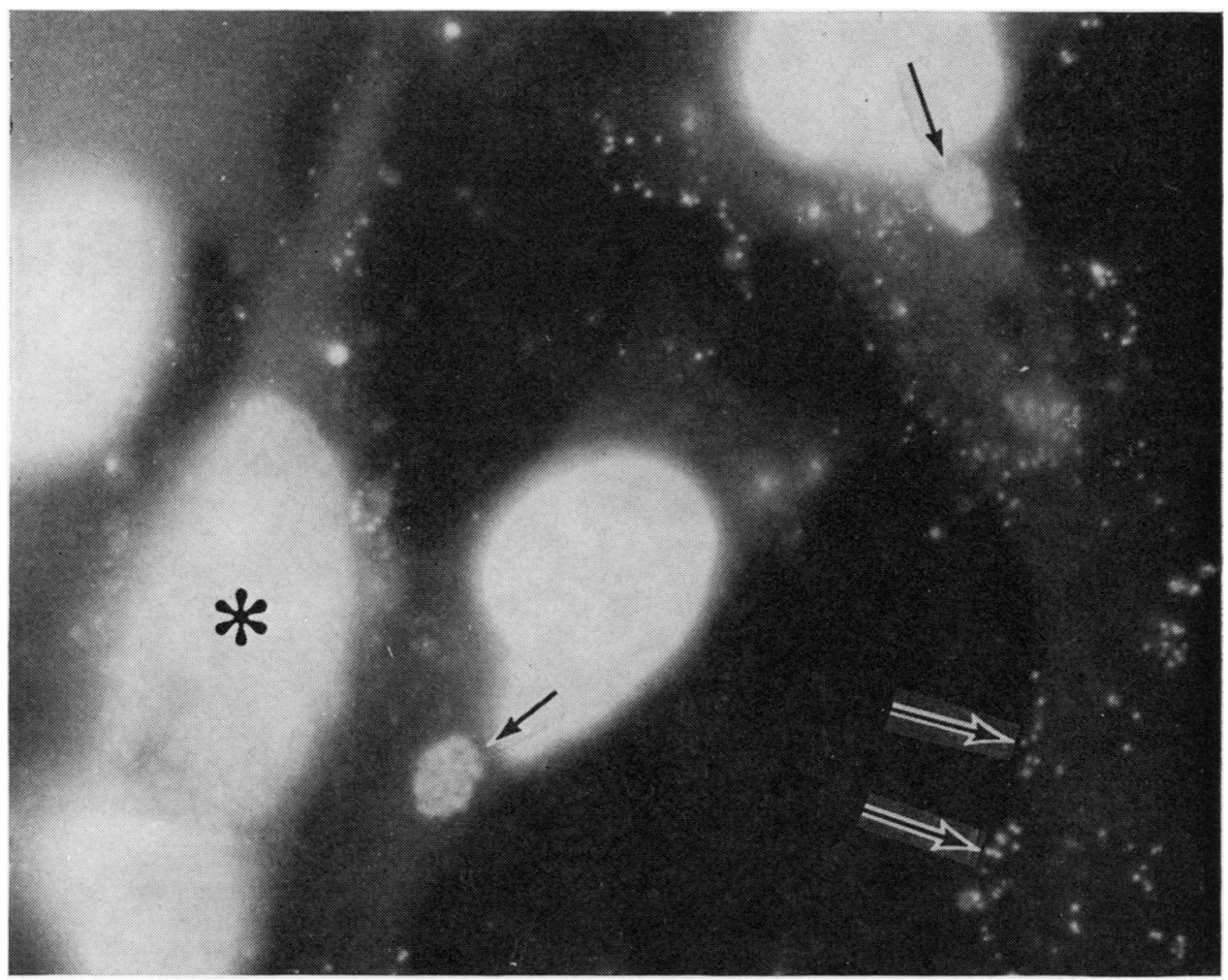

Fig. 5 HeLa 229 cells after infection for 72 hours with C. trachomatis UW4, stained with Hoechst 33258. Brightly stained, small, DNA rich particles (solid arrows) can be seen adherent to the surfaces of the tissue culture cells; these particles are comparable to those seen in chlamydial infected egg yolk sac (Fig. 7) and represent chlamydial elementary bodies. A mature primary inclusion (*) is present as well as two small inclusions (hollow arrows) comparable to those seen after 18 hours' infection (Fig. 3). These may be late developing primary inclusions or, more likely, a new cycle of infection in the previously uninfected cells. $\times 550$.

diseased fallopian tubes in $30 \%$ of patients with acute salpingitis (Mårdh et al., 1977) while maternal infections have been associated with prematurity, pneumonia, and eye infections in the newborn (Rees et al., 1977; Beem and Saxon, 1977). Chlamydial infections are resistant to penicillins, cephalosporins, chloramphenicol, and aminoglycosides. Therefore, only rapid diagnosis would permit early treatment with erythromycin or tetracyclines.

Chlamydiae can be rapidly detected using fluorescent antibody techniques (Thomas et al., 1977). However, appropriate fluorescent antisera are not readily available, and, like other fluorescent antibody techniques, the method is time-consuming and requires considerable expertise. For this reason, relatively insensitive and non-specific conventional staining techniques are most commonly used for detecting chlamydiae, the morphology of mature chlamydial inclusions being sufficiently characteristic to permit definite identification. However, diagnosis of chlamydial infection might be made earlier by combining the specificity of modern DNA binding dyes with the sensitivity of fluorescence techniques.

Acridine orange is the classic fluorescent dye for staining virus-infected cells. Unfortunately, acridine orange reacts with RNA as well as DNA and was found to stain both the host cell cytoplasm and the developing reticulate bodies, making it difficult to detect early chlamydial maturation. Recently, two fluorescent dyes, DAPI and Hoechst 33258, have become available which act by non-intercalative binding to the adenine-thymine rich areas of doublestranded nucleic acid and which are highly specific for DNA (Arndt-Jovin and Jovin, 1977). 


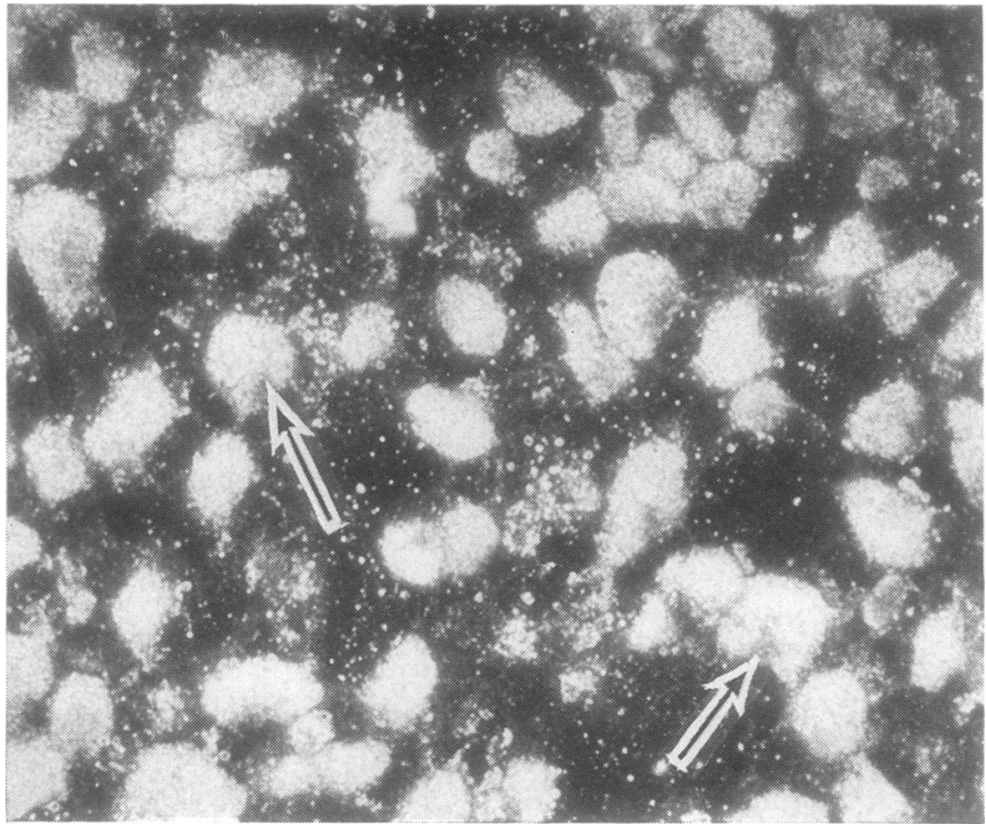

Fig. 6 Monolayer of HeLa 229 cells heavily infected for 72 hours with C. trachomatis UW4, stained with the conventional Giemsa method, and examined by dark-ground light microscopy. 72-hour inclusions such as these (arrows) are readily visualised by both techniques. However, unlike the Hoechst stain, the Giemsa method does not permit ready identification of early inclusions such as those of Fig. 3. $\times$ 350.

DAPI has been used for the spectrofluorimetric assay of DNA and, in the presence of RNA, can detect as little as $5 \times 10^{-10} \mathrm{~g} / \mathrm{ml}$ of DNA (Kapuściński and Skoczylas, 1977). DAPI can be used for the detection of DNA viruses and mycoplasma in vitro (Russell et al., 1975). Most of the experiments described here were performed using Hoechst 33258 because of its ready availability; however, comparable results were obtained using DAPI, and this is now commercially available.

The method described has significant advantages. The staining technique is rapid, taking some 15 minutes as opposed to the 1 hour plus of Giemsa or fluorescent antibody staining. Only chlamydiae and host cell nuclei are stained; there is thus no possibility of confusing chlamydiae with host cell cytoplasmic components. Moreover, with incident or transmitted dark-ground illumination the chlamydiae are viewed under ideal contrast conditions: bright light blue fluorescence against a black background. The technique is far more sensitive than Giemsa staining; with both DAPI and Hoechst 33258 chlamydial inclusions in HeLa 229 cells can readily be identified after 18 hours' growth. The presence of $1 \mu \mathrm{g} / \mathrm{ml}$ of emetine hydrochloride in the tissue culture medium during incubation of the chlamydial infected cells markedly increases the size of early (18 and 24 hour) chlamydial inclusions and prevents overgrowth of the host cells, making identification even easier. Emetine selectively blocks protein synthesis in eukaryotic host cells but leaves chlamydial (prokaryotic) protein synthesis unimpaired, favouring chlamydiae in their competition with the host cell for intracellular amino acid pools (Becker and Asher, 1972).

In our laboratory, clinical specimens for chlamydial culture are centrifuged on to monolayers of DEAE-dextran treated HeLa 229 cells followed by incubation of the infected cells in emetine-containing tissue culture medium before Hoechst staining. Isotope studies on chlamydial amino acid utilisation by strain UW4 growing in emetine-treated cells (data not shown) shows there is little point in incubating infected cells beyond some 40 hours. Beyond this point, loss of cells from the monolayer due to chlamydial release and the effects of emetine 


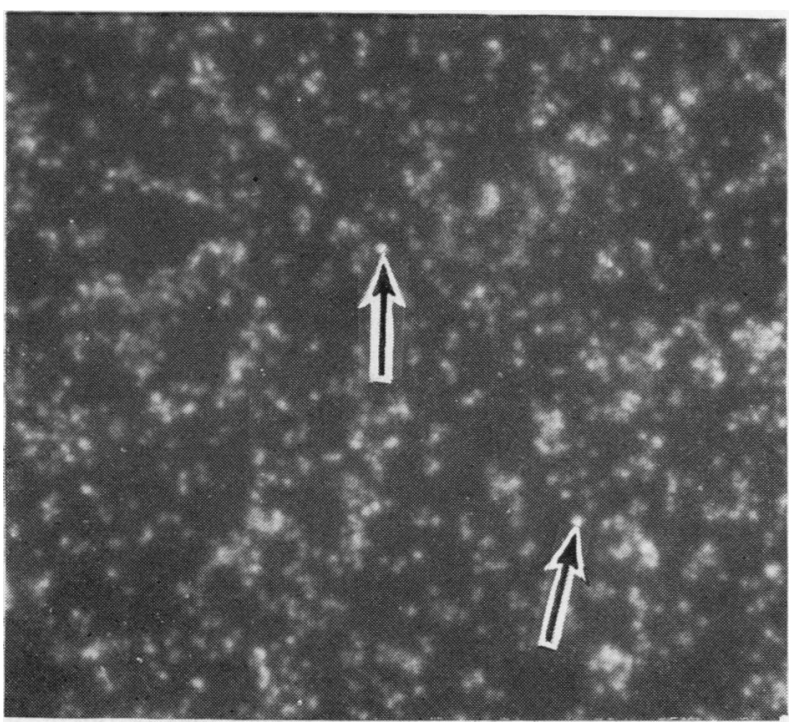

Fig. 7 Hoechst 33258 stained smear of a $50 \%$ $v / v E L D_{50}$ homogenate of $\mathrm{C}$. trachomatis $U W 4$ grown in the embryonated hen yolk sac. Small particles of brightly fluorescent chlamydial elementary bodies (arrows) stain brightly with the Hoechst stain and are absent from control uninfected preparations. $\times 550$.

exceeds the rate of isotope incorporation due to continuing chlamydial multiplication. In practice, no difficulties have been experienced in identifying Hoechst stained inclusions from clinical specimens in HeLa cell monolayers. Most of the DNAcontaining debris likely to be encounteredbacteria, yeasts, white cells, epithelia-is washed from the preparations before and after staining, and it is, in any case, quite unlike the characteristic chlamydial inclusions. Inclusions of DNA-containing viruses (eg, herpes, adenovirus) could theoretically be detected by Hoechst staining; indeed, this might be useful for the diagnosis of nonbacterial eye infections. However, Hoechst-stained virus inclusions are unlikely to be confused with chlamydial inclusions and would not be expected to develop in metabolically inhibited emetine or cycloheximide treated host cells. Hoechst stain has been successfully used in our laboratory for the direct microscopic detection of chlamydiae in clinical specimens. However, insufficient experience has yet been gained to know how useful it will be in this respect when compared with Giemsa stain.

The disadvantage of the Hoechst stain is its requirement for a fluorescence microscope with suitable filtration for the $365 \mathrm{~nm}$ excitation and 450-500 nm emission spectrum of the dyes. However, most diagnostic microbiology laboratories have facilities for fluorescence microscopy. Incident light illumination of the specimen is preferable, but dark-ground transmitted illumination can be used. Thus, for most laboratories the only extra capital cost will be a suitable excitation and barrier filter.
By comparison with fluorescein conjugates used for immunofluorescence, Hoechst 33258 stained material usually fluoresces much brighter, is stable on storage, and is more resistant to ultraviolet induced fading.

\section{References}

Arndt-Jovin, D. J., and Jovin, T. M. (1977). Analysis and sorting of living cells according to DNA content. Journal of Histochemistry and Cytochemistry, 25, 585-589.

Becker, Y., and Asher, Y. (1972). Synthesis of trachoma agent proteins in emetine-treated cells. Journal of Bacteriology, 109, 966-970.

Beem, M. O., and Saxon, E. M. (1977). Respiratorytract colonization and a distinctive pneumonia syndrome in infants infected with Chlamydia trachomatis. New England Journal of Medicine, 296, 306-310.

Darougar, S., Kinnison, J. R., and Jones, B. R. (1971). Simplified irradiated McCoy cell culture for isolation of chlamydiae. In Trachoma and Related Disorders Caused by Chlamydial Agents (Excerpta Medica International Congress Series, 223), edited by R. L. Nichols, pp. 63-70. Excerpta Medica, Amsterdam.

Johnson, F. W. A. (1975). A comparison of staining techniques for demonstrating group A chlamydia in tissue culture. Medical Laboratory Technology, 32, 233-238.

Kapuściński, J., and Skoczylas, B. (1977). Simple and rapid fluorimetric method for DNA microassay. Analytical Biochemistry, 83, 252-257.

Kuo, C. C., Kenny, G. E., and Wang, S. P. (1971). Trachoma and psittacosis antigens in agar gel double immunodiffusion. In Trachoma and Related Disorders Caused by Chlamydial Agents (Excerpta Medica 
International Congress Series, 233), edited by $\mathbf{R}$. L. Nichols, pp. 113-123. Excerpta Medica, Amsterdam.

Kuo, C. C., Wang, S. P., and Grayston, J. T. (1972). Differentiation of TRIC and LGV organisms based on infectivity by DEAE-dextran in cell culture. Journal of Infectious Diseases, 125, 313-317.

Mårdh, P. A., Ripa, T., Svensson, L., and Weström, L. (1977). Chlamydia trachomatis infection in patients with acute salpingitis. New England Journal of Medicine, 296, 1377-1379.

Rees, E., Tait, I. A., Hobson, D., and Johnson, F. W. A. (1977). Perinatal chlamydial infection. In Non Gonococcal Urethritis and Related Infections, edited by D. Hobson and K. K. Holmes, pp. 140-147. American Society for Microbiology, Washington, DC.
Russell, W. C., Newman, C., and Williamson, D. H. (1975). A simple cytochemical technique for demonstration of DNA in cells infected with mycoplasmas and viruses. Nature, 253, 461-462.

Thomas, B. J., Evans, R. T., Hutchinson, G. R., and Taylor-Robinson, D. (1977). Early detection of chlamydial inclusions combining the use of cycloheximide-treated McCoy cells and immunofluorescence staining. Journal of Clinical Microbiology, 6, 285-292.

Requests for reprints to: Dr M. E. Ward, University Microbiology, South Laboratory and Pathology Block, Southampton General Hospital, Tremona Road, Southampton SO9 4XY.

\section{Reports and Bulletins prepared by the Association of Clinical Biochemists}

The following reports and bulletins are published by the Association of Clinical Biochemists. They may be obtained from The Publishing Department, British Medical Journal (ACB Technical Bulletins), B.M.A. House, Tavistock Square, London WC1H 9JR. Overseas readers should remit by British Postal or Money Order.

SCIENTIFIC REVIEWS (price $£ 1 \cdot 00 / \$ 2.00$ each)

1 The assessment of thyroid function March 1971 F. V. FLYNN and J. R. HOBBS

2 Renal function tests suitable for clinical practice January 1972 F. L. MITCHELL, N. VEALL, and R. W. E. WATTS

3 Biochemical tests for the assessment of fetoplacental function May 1975 C. E. WILDE and R. E. OAKEY

4 Test of exocrine pancreatic function March 1977 A. H. GOWENLOCK

5 Assay of cholinesterase in clinical chemistry March 1979 ELSIE SILK, J. KING, and MARY WHITTAKER

TECHNICAL BULLETINS (price $£ 1 \cdot 00 / \$ 2.00$ each)

22 Bilirubin standards and the determination of bilirubin by manual and technicon AutoAnalyzer methods January 1971 BARBARA BILLING, RUTH HASLAM, and N. WALD

23 Interchangeable cells for spectrophotometers and fluorimeters September 1971 S. S. BROWN and A. H. GOWENLOCK

24 Simple tests to detect poisons March 1972 B. w. MEADE et al.

25 Blood gas analysers May 1972 K. DIxoN

26 Kits for enzyme activity determination September 1972 S. B. ROSALKI and D. TARLOW

27 Assessment of pumps suitable for incorporation into existing continuous flow analytical systems November 1972 A. FLECK et al.
28 Routine clinical measurements of transferrin in human serum September 1973 K. DIXON

29 Control materials for clinical biochemistry (5th edition) September 1973 J. F. STEVENS

30 Notes on the quality of performance of serum cholesterol assays September 1973 S. S. BROWN

31 Determination of uric acid in blood and in urine July 1974 R. W. E. WATTS

32 A survey of amino acid analysers readily available in the United Kingdom September 1974 J. B. CARLYLB and P. PURKISS

33 Definitions of some words and terms used in automated analysis November 1974 A. FLECK, R. ROBINSON, S. S. BROWN, and J. R. HOBBS

34 Measurement of albumin in the sera of patients January 1975 LINDA SLATER, P. M. CARTER, and J. R. HOBBS

35 Investigation of the validity of temperature correction factors for serum aspartate and alanine transaminases March 1975 S. B. ROSALKI et al.

36 Factors influencing the assay of creatinine November 1975 J. G. H. COOK

37 A survey of enzyme reaction rate analysers readily available in the United Kingdom July 1977 R. A. SAUNDERS and R. F. BURNS

38 Transport of specimens for clinical chemistry analysis November 1977 P. WILDING, J. P. ZILVA, and C. E. WILDE

39 A scheme for the evaluation of diagnostic kits May 1978 P. H. LLOYD 